Accepted refereed manuscript of:

Lee B \& Veld-Merkoulova Y (2016) Myopic Loss Aversion and Stock Investments: An Empirical Study of Private Investors, Journal of Banking and Finance, 70, pp. 235-246. DOI: $10.1016 / j . j$ bankfin.2016.04.008

(C) 2016, Elsevier. Licensed under the Creative Commons Attribution-NonCommercial-NoDerivatives 4.0 International http://creativecommons.org/licenses/by-nc-nd/4.0/ 


\section{Accepted Manuscript}

Myopic Loss Aversion and Stock Investments: An Empirical Study of Private Investors

Boram Lee, Yulia Veld-Merkoulova

PII: S0378-4266(16)30040-1

DOI: http://dx.doi.org/10.1016/j.jbankfin.2016.04.008

Reference: JBF 4937

To appear in: Journal of Banking \& Finance

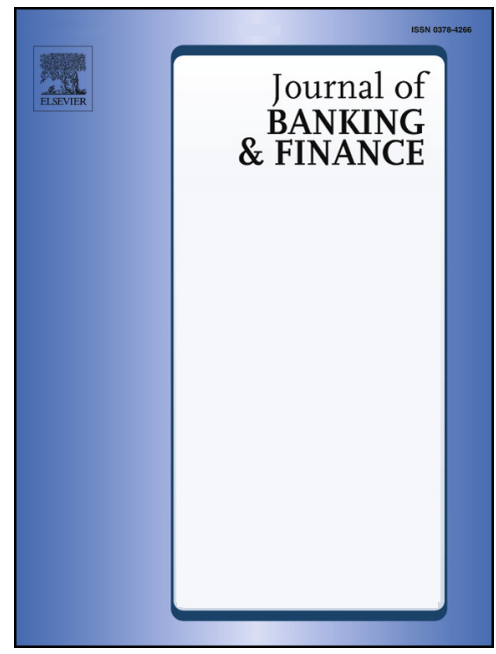

Received Date: $\quad 30$ December 2014

Accepted Date: $\quad 15$ April 2016

Please cite this article as: Lee, B., Veld-Merkoulova, Y., Myopic Loss Aversion and Stock Investments: An Empirical Study of Private Investors, Journal of Banking \& Finance (2016), doi: http://dx.doi.org/10.1016/ j.jbankfin.2016.04.008

This is a PDF file of an unedited manuscript that has been accepted for publication. As a service to our customers we are providing this early version of the manuscript. The manuscript will undergo copyediting, typesetting, and review of the resulting proof before it is published in its final form. Please note that during the production process errors may be discovered which could affect the content, and all legal disclaimers that apply to the journal pertain. 


\title{
Myopic Loss Aversion and Stock Investments: An Empirical Study of Private Investors
}

\author{
Boram Lee \\ Yulia Veld-Merkoulova
}

February 29, 2016

\begin{abstract}
Myopic loss aversion was suggested by Benartzi and Thaler (1995) as an explanation for the equity premium puzzle. Its main prediction is that loss averse investors, who evaluate their investment performance too frequently and therefore often observe small losses on their stock portfolios, would invest too little in equity. We investigate the link between myopic loss aversion and actual investment decisions of individual investors, using survey data. Our results are consistent with the predictions of Benartzi and Thaler. Higher myopic loss aversion is associated with lower stock investment as a share of total assets. Investors tend to evaluate their stock portfolio performance too often, which contributes to the prevalence of myopic loss aversion. The effect of myopia is most apparent when investors both evaluate their portfolios frequently and trade stocks regularly.
\end{abstract}

Keywords: Portfolio Allocation, Myopic Loss Aversion, Individual Investors. JEL Classification: D14, D91, G11.

Dr. Boram Lee is in the Accounting and Finance Division, Stirling Management School, University of Stirling, UK (e-mail: boram.lee@stir.ac.uk). Dr. Yulia Veld-Merkoulova is at Monash University, Caulfield, Vic 3145, Australia (e-mail: Yulia.Veld-Merkoulova@ Monash.edu).

We thank Chris Veld, Christopher Baum, Steve Bond, Stephen Brown, Stephen Dimmock, Roy Kouwenberg, Jordan Neyland and participants at the 2012 Western Economic Association International meeting, the 1st Conference on Recent Developments in Financial Econometrics and Applications, 2015 FIRN Annual Meeting, and a seminar at Macquarie University for their helpful comments and suggestions. Special thanks go to the editor, Geert Bekaert, and an anonymous referee. In this paper use is made of data of the DNB Household Survey. The financial support of the Dutch Science Organization (NWO; A laboratory for the use of household financial decisions) is gratefully acknowledged. 


\section{Introduction}

The equity premium puzzle of Mehra and Prescott (1985) highlights the abnormally high difference between the returns on the S\&P 500 and risk-free Treasury bills observed between 1889 and 1978. Unless investors have implausibly high levels of risk aversion, the historical average equity premium of $6 \%$ is too high to be justified by standard economic models. Responding to this puzzle, Benartzi and Thaler (1995) propose the concept of myopic loss aversion (MLA), which describes the tendency of loss-averse investors to evaluate their portfolios too frequently and consequently to invest too little in risky assets ${ }^{1}$. Using simulations, Benartzi and Thaler demonstrate that when investors evaluate their portfolios annually, the size of the equity premium is consistent with parameters estimated in prospect theory (Tversky and Kahneman, 1992) ${ }^{2}$. Thaler et al. (1997), Gneezy and Potters (1997), Haigh and List (2005), and Eriksen and Kvaløy (2010) support the existence of MLA in experimental settings, finding that when portfolio evaluation or rebalancing frequency is reduced, subjects increase their investment in risky assets.

Most previous studies on MLA are experimental and use students as subjects for investment allocation simulations, ${ }^{3}$ which means that we do not know with certainty whether these results reflect the real-life decision-making of investors. We fill this gap by surveying a representative cross-section of individuals, and testing whether their MLA is correlated with their actual equity investment.

We explicitly account for the joint effects of myopia and loss aversion, rather than merely studying them in isolation. Following Benartzi and Thaler (1995), we define MLA as

\footnotetext{
${ }^{1}$ A related, and more theoretically tractable, alternative to MLA is the Disappointment Aversion framework of Gul (1991). Its application to the portfolio choice problem is extensively discussed by Ang, Bekaert and Liu (2005).

${ }^{2}$ However, Ang, Bekaert and Liu (2005) show that the optimal asset allocation solution found by Benartzi and Thaler is limited to the no-borrowing (and no-short-selling) case, and that no finite solution exists in the general case. If leverage is not restricted, the loss averse investor's utility is maximized when equity investment approaches infinity.

${ }^{3}$ Exceptions are Haigh and List (2005) and Eriksen and Kvaløy (2010), who conduct their experiments with professional traders.
} 
a combination of individual investors' levels of myopia and loss aversion. Examining these two effects together is important because the fundamental concept of MLA is built on their interaction. To the best of our knowledge, our study is the first empirical study of MLA to focus on the relationship between both investors' myopia and loss aversion and their equity investments. Dimmock and Kouwenberg (2010) also analyse the investment decisions of individual investors with real-life data, but focus exclusively on loss aversion as an explanation for household portfolio choice. They do not address the effects of investors' myopia or MLA. Kliger and Levit (2009) focus on the market return and volatility of a small number of stocks that have their trading frequency changed by the stock exchange. While their results are supportive of the MLA hypothesis, their data does not include the majority of the traded stocks, making these results difficult to extend to full investors' portfolios.

The concept of myopia was originally developed on the basis of portfolio evaluation frequency only. Gneezy, Kapteyn, and Potters (2003), however, suggest rebalancing frequency as another important proxy for myopia. Subsequent experimental studies have attempted to disentangle the effects of evaluation and rebalancing frequencies, although findings conflict to some extent. Bellemare et al. (2005) argue that evaluation frequency alone determines myopia, while Langer and Weber (2008) find that rebalancing frequency is the sole driving force. Fellner and Sutter (2009) conclude that both variables contribute to the effects of myopia. They demonstrate in a multi-period experimental setting that subjects have a clear preference for more frequent evaluation and rebalancing. To measure myopia, we survey investors on both their evaluation and rebalancing frequencies.

We investigate the link between MLA and the share of investors' total financial assets invested in equity, as well as yearly changes in equity allocation over our sample period. We find that the level of MLA is negatively correlated with the proportion of individual portfolios invested in equities. Among highly loss averse individuals, high levels of both evaluation and 
rebalancing frequencies are associated with a relatively low equity holding. This result is driven by both loss aversion and myopia and is consistent with the main predictions of Benartzi and Thaler (1995).

Our evidence also suggests that the simulations results of Benartzi and Thaler (1995) are based on plausible assumptions, with the median investor in our sample evaluating her investment results quarterly and rebalancing her portfolio less than once a year. This result is in line with the experiment of Fellner and Sutter (2009), who find that most subjects display a strong preference for a high evaluation frequency and a somewhat less pronounced preference for short investment horizons.

When we investigate changes in the proportion of equity investments, the effect of myopia on investors' decisions dominates that of loss aversion. Investors, who evaluate their holdings less frequently, increase their holdings over time more than those who check their performance at least monthly. This result is robust to controlling for changes in the level of investments due to stock market fluctuations.

The remainder of the paper is organised as follows. In Section 2 we explain our survey data collection procedure and the construction of variables. In Section 3 we present our models and empirical results. Finally, we summarise and conclude our study in Section 4.

\section{Data Description and Construction of Variables}

\section{Sample Selection}

We use the survey data from the CentERdata, a specialised online research institute at Tilburg University in the Netherlands. It consists of over 2,000 households including individuals over 16 years of age and representative of the Dutch population in respect of a number of important demographic characteristics. This panel has been used extensively in academic research; for instance, Van Rooij, Lusardi, and Alessie $(2011 ; 2012)$ use it to study 
the effects of financial literacy on individual stock market participation and wealth, Dong, Robinson, and Veld (2005) study the preferences of individual investors on dividend payments, and Guiso, Sapienza, and Zingales (2008) investigate the relationship between trust and stock market participation.

In 2003, we submitted a survey on MLA to the CentERdata panel and 2,226 panel members participated ${ }^{4}$. Since the survey focused on investors' portfolio evaluation and rebalancing frequencies, it was addressed only to those who invest in equities (stocks and mutual funds). ${ }^{5}$ From those 2,226 individuals, we obtain responses from 687 investors, indicating that about $30 \%$ of the contacted panel members are investors. This percentage is comparable to the equity ownership rates in the Netherlands reported by Alessie, Hochguertel, and van Soest (2004), and Dimmock and Kouwenberg (2010). We combine the survey on MLA with the Dutch National Bank Household survey (DHS) which includes extensive financial, demographic and psychological information. The DHS survey has been undertaken annually by the panel since 1993 . We first merge the MLA survey with intertemporal choice questions from the Economics and Psychological Concepts section of the DHS, which enables us to estimate individuals' loss aversion and discount rates. These questions are only available for the period 1997-2002. Due to the unavailability of these questions after 2002, there are a large number of missing values reducing the sample size to 407 . We further incorporate the time preference question from the DHS for the year 2003; for the resulting additional $5 \%$ of missing values, we impute values reported for the time preference question in the years 2002 and/or 2004 for the same individuals, although these data are missing for 4 individuals. Finally, we merge our dataset with the assets and liabilities section of the DHS for the period 1997 (the first year for which the intertemporal questions are available) to 2010,

\footnotetext{
${ }^{4}$ As this survey was conducted only once, we cannot test for the variations in the levels of myopia over time, and we carry out our tests under the assumption that individuals' MLA remains constant.

${ }^{5}$ In this paper, we investigate the relationship between the effects of myopic loss aversion and individual investors' portfolio allocation decisions in accordance with the theory suggested by Benartzi and Thaler (1995). Thus the question of what determines stock market participation falls outwith the scope of the study.
} 
making 14 years of asset allocation data in total. We lose a further 3 individuals who fail to report their assets and liabilities throughout the period. Panel A of Table 1 presents our sample selection process and Panel B shows the demographic characteristics of our sample in 2003.

[Table 1 here]

Our unbalanced panel includes 400 individuals who appear on average for 8 years, making a total of 3,347 observations for the period from 1997 to $2010.70 \%$ are men and $30 \%$ are women. Their ages range from 20 to 88 , with an average age of 52 . About $80 \%$ are married, and $57 \%$ have either a college or university education. Our sample, which includes investors only, is more representative of actual stock market investors than of general population, thus biased towards older, married and better-educated male respondents.

\section{Financial Variables}

We incorporate the aggregated assets and liabilities values from the annual DHS for the period 1997 to 2010 . All financial values are as at $31^{\text {st }}$ December of the preceding year. We winsorise all financial variables by replacing all observations in the top percentile at the value of the $99^{\text {th }}$ percentile. Following Alessie, Hochguertel, and van Soest (2002), we define Total financial assets as the sum of positive balances on Checking accounts, Employer sponsored savings plans, ${ }^{6}$ Savings accounts, Deposit books, Savings certificate, Singlepremium annuity insurance policies, ${ }^{7}$ Savings and endowment insurance policies, ${ }^{8}$ Mutual funds, Bonds, Stocks, Options, Money lent to friends and family, and Other savings or

\section{investments.}

\footnotetext{
${ }^{6}$ These plans are a unique asset class, designed to encourage employees to participate in wealth accumulation (Alessie et al., 2000). They work as 'save-as-you-earn' deduction arrangements, automatically depositing a certain amount from individuals' gross salaries in a separate savings account.

${ }^{7}$ As a common form of defined contribution (DC) pension plan, these involve a one-time premium payment, which is tax deductible. Individuals who have taken out these plans report the amount of the guaranteed minimum final payment if their plans are still in effect.

${ }^{8}$ As a form of life insurance, endowment insurance policies are known as 'insured saving', providing a lump sum at maturity rather than an annuity. Although premium payments are not tax deductible, the lump sum received at maturity is.
} 
Equity is calculated as the sum of Individual company shares and Mutual funds ${ }^{9}$. Our main variable of interest is the weight of equity investment within a portfolio, which is comparable to the endowed capital allocated to risky gambles in experimental studies.

In Panel $\mathrm{C}$ of Table 1, we present average equity ownership rates over our sample period. These rates are below $100 \%$ since individuals in our sample tend to exit and re-enter the equity market from time to time. Descriptive statistics for the overall equity portfolio weight, and for Shares and Mutual funds separately together with the average total annual return on the Dutch stock market index, AEX, are reported.

To control for the credit constraints, which may influence investors' investment capability (Cocco, 2004; Cocco, Gomes and Maenhout, 2005), we create a Debt Ratio variable equal to a ratio of individuals' total debts to total assets. Total assets comprise financial assets and fixed assets including Real estate, Owners' houses and the Cash value of insurance on real estate and owners' houses. Debts include Negative current accounts balances, Private loans, Extended lines of credit, Debts with mail-order firms, Loans from family and friends, Student loans, Credit card debts, and Other debts, as well as Mortgages on real estate and owners' houses.

\section{Measuring the Level of Myopia}

To define the level of myopia, we focus on two separate measures: portfolio evaluation frequency and rebalancing frequency. We ask investors about their evaluation and rebalancing frequencies by providing 'daily', 'weekly', 'monthly', 'quarterly', 'annually', and 'less often than annually' options for both questions, following the 'choice bracketing' approach of Read, Loewenstein and Rabin (1999). The question on evaluation frequency is

\footnotetext{
${ }^{9}$ We do not include Options or Bonds in the risky financial asset category, due to their distinctive characteristics, and the possibility of hedging. If individuals hold any put or call options, they report the total amounts paid for them on acquisition or the total market value when the option was written. Bonds are often considered riskless assets, and the DHS data does not distinguish between government and corporate bonds. Alessie et al. (2000) find that Bonds are an unpopular asset type in the Netherlands.
} 
presented as: "How often do you evaluate the performance of your stock portfolio on average? An evaluation can take different forms. It can, for example, vary from including recent prices in a spread sheet to simply checking in newspapers or on Teletext ${ }^{10}$ how the shares perform."

The question on rebalancing frequency is presented as: "How often do you change your stock portfolio by buying or selling shares without the need for cash?"

We follow the design of Gneezy and Potters (1997) in order to disentangle the effects of evaluation frequency from rebalancing frequency, adopting a 2-by-2 design where both frequencies are divided into two levels, High and Low. Similar approaches were also used by Langer and Weber (2008), and Fellner and Sutter (2009).

Our survey results are presented in Table 2 . We observe that individuals' evaluation frequencies are spread evenly from 'daily' to 'less often than annually'. $44 \%$ of individuals choose to evaluate their portfolio performance either monthly or more frequently. Such frequent evaluation exposes individuals to observing portfolio losses on a regular basis, which in turn may be detrimental to their propensity to invest in stocks and to their aggregate wealth. These results reflect the very strong preferences for frequent feedback identified in the experimental study of Fellner and Sutter (2009).

[Table 2 here]

In assessing rebalancing frequency, however, $70 \%$ of investors in our sample indicate that they rebalance their portfolios less often than annually. Investors opt for low rebalancing frequency, conflicting with the argument that investors generally prefer high rebalancing frequency (Fellner and Sutter, 2009), or over-trade due to overconfidence (Odean, 1999; Barber and Odean, 2000; 2001). Our results are consistent with those of Agnew, Balduzzi, and Sundén (2003), who find that individual investors in 401(k) Plans trade infrequently, with

\footnotetext{
${ }^{10}$ Teletext is a data broadcasting service in which pre-programmed sequences of frames of data are broadcast cyclically.
} 
over $87 \%$ of their sample maintaining their allocation for at least one year and, on average, rebalancing every 3.85 years.

As expected, those investors who trade frequently are also more likely to evaluate their performance more often. The correlation between the evaluation and rebalancing frequency variables is positive and significant at the $0.1 \%$ level. However, these two variables are by no means perfect substitutes (the correlation coefficient is equal to 0.31 ). We divide both variables into high and low at their median values. In the case of evaluation frequency, we allocate individuals from 'daily' to 'monthly' to High level (44\%) and from 'quarterly' to 'less than annually' to Low level (56\%). In the case of rebalancing frequency, we define frequencies from 'daily' to 'annually' as High level (30\%) and define frequency of 'less than annually' as Low level (70\%).

Consequently, we categorise 400 individuals into four groups, which allows us to disentangle the two variables, and assess the effect of varying levels of myopia. We allocate 70 individuals (17.5\%) into the 'High Evaluation with High Rebalancing frequency' group (HEHR); 107 individuals (26.75\%) into the 'High Evaluation with Low Rebalancing frequency' group (HELR); 50 individuals (12.5\%) into the 'Low Evaluation with High Rebalancing frequency' group (LEHR); and 173 individuals (43.25\%) into the 'Low Evaluation with Low Rebalancing frequency' group (LELR) as listed in Table 2.

\section{Measuring Individuals' Loss Aversion Coefficients and Discount Rates}

During 1997-2002, the DHS included 16 hypothetical intertemporal choice questions developed by Tu (2004) based on experimental work by Thaler (1981) and Loewenstein (1988). The discounted utility (DU) model assumes that when comparing intertemporal choices, decision makers have a single discount rate for gains and losses, and for delaying and speeding-up payments. Thaler (1981) and Loewenstein (1988), however, contest the assumption that individuals' self-determined discount rates vary in different situations, since 
individuals demand a premium for delaying a sure payment which is greater than the cost incurred for speeding-up the same amount.

In particular, individuals have different discount rates for gains and losses, and qualitatively different attitudes towards borrowing and lending (Loewenstein and Prelec, 1992). This intertemporal choice model incorporates the loss aversion effects of individuals in terms of framing their gains and losses relative to their subjective discount rates. Loewenstein (1988) specifies three terms to define individuals' preferences: the immediate consumption price, the delayed consumption price, and the speeding-up consumption price. The delayed premium cost is a compensation for delay as opposed to immediate consumption, and the speeding-up cost is a sacrifice made in order to advance delayed to immediate consumption.

The sixteen questions developed by Tu (2004) differ by four components: delaying $(D)$ vs. speeding-up $(S)$ a payment; gains $(G)$ vs. losses $(L)$; a time dimension $(T)$ of 3 months vs. 1 year; and a payment $(X)$ of $f 1,000$ vs. $f 100,000$ in Dutch guilders. The gains occur as a result of winning a prize in the National lottery, and the losses as a result of a tax assessment. The Delay of Gain questions, for example, ask an individual to state the required additional amount to compensate for postponing the prize of $f 1,000$ for one year. Questions on (1) 'Delay of a Gain' and (2) 'Speed-up of a loss' with an amount of f1,000 for a 1 year time dimension are presented as below.

(1) 'Imagine that you win a prize of $f 1,000(€ 454)$ in the National Lottery. The prize is to be paid out today. Imagine, however, that the lottery asks if you are prepared to wait A YEAR before you get the prize (there is no risk involved in this wait). How much extra money would you ask to receive to compensate you for the waiting term of a year? If you agree on the waiting term without the need to receive extra money for that, please type 0 (zero) - AT LEAST a compensation of $\underline{f}$.' 
(2) 'Imagine that you receive a tax assessment of $f 1,000$ (€454). The assessment has

to be settled within A YEAR. It is, however, possible to settle the assessment now, and in that case you will get a REDUCTION. How much of a REDUCTION would you require to receive for settling the assessment now instead of after a year? If you are not interested in receiving a reduction for paying early or if you think there is no need to receive a reduction for paying early, please type 0 (zero) - AT LEAST a reduction of $\boldsymbol{f}$

The Delay of Gain (DG) question (1) asks an individual to state the additional amount required to compensate her for postponing the prize of $f 1,000$ for one year. If the individual indicates $f 200$, this amount compensates for the waiting time of one year, and a final payment of $f 1,200$ would be made in this case. Similarly, the Speed-up of a Loss (SL) question (2) is framed to identify by how much an individual would expect to reduce their final payments by expediting the future payment. If the individual states $f 200$ to be his required reduction, the tax assessment will be reduced to $f 800$, to be paid immediately. From the answers to the 16 questions, we winsorise extreme values and undertake a validity check for two types of judgment errors following the approach of Dimmock and Kouwenberg (2010). First, we discard respondents who answer zero to all questions each year as we assume that they did not fully consider the questions ${ }^{11}$. Second, we winsorise individuals' responses to control for extreme values at $X(f 1,000$ or $f 100,000)$ for the $D G$ questions and at $50 \%$ of $X$ for the other questions. We also compare the answers on the set of four questions for each situation in order to identify and discard any responses displaying judgment errors.

\footnotetext{
${ }^{11}$ About $3 \%$ to $5 \%$ of observations are deleted due to individuals who answer zero to all questions each year. Although it is possible that those individuals are not loss averse and hold a zero discount rate, it is impossible to determine whether their responses do indeed reflect this or whether, alternatively, are simply due to a lack of interest in participating in the survey. Following the approach of Dimmock and Kouwenberg (2010), therefore, we discard them.
} 
For instance, the four questions on the $D G$ situation, vary with $X$ amount of either $f 1,000$ or $f 100,000$ and a horizon $T$ of either three months or one year. Thus if a respondent demands a greater amount as a premium for delaying a gain for 3 months rather than delaying for one year, for the same amount or, alternatively, if a respondent demands a greater amount as premium for delaying $f 1,000$ rather than $f 100,000$, for the same time period, we consider such anomalous responses to be judgment errors and discard them. Thaler (1981) and Loewenstein and Prelec (1992) emphasise that dynamic inconsistency of time-preferences affects intertemporal choices independently of loss aversion effects; thus we exclude questions with a time dimension of three months to avoid such discrepancies.

[Table 3 here]

Descriptive statistics for responses to the eight questions with a time dimension of one year are presented in Panel A of Table 3. Individuals in our sample demand the highest premium for the Delay of Gain (DG) questions as compared to all other situations. The mean value of $17.82 \%$ for the premium ratio indicates that individuals demand $f 178.2$ on average as their premium for delaying a gain of $f 1,000$ for one year. For the delay of losses, on the other hand, individuals only expect to pay $f 30.6$ (or $3.06 \%$ ) to delay a payment of $f 1,000$ for one year. They expect to incur lesser amounts to delay losses and speed-up gains, while requiring a high reduction from the speed-up of losses. These deviations violate the notions of conventional discounted utility (DU), which proposes the same discount rate for both borrowing and lending.

From the calculated ratios for each of the intertemporal choice questions, we derive equations based on the full reference point adjustment model of Loewenstein (1988), which provides the most effective results according to the findings of Dimmock and Kouwenberg (2010). Using Generalized Methods of Moments (GMM) estimations to minimise the sum of the squared errors, we derive two parameters i.e. the loss aversion coefficient and discount 
rate, from the eight moments situations. Descriptive statistics for the two parameters are presented in Panel B of Table 3. The loss aversion coefficient and discount rate are estimated for each individual based on their average responses over the period 1997-2002. When the two parameters are calculated, the GMM estimations report standard errors for each parameter and for each individual. Thus we also report descriptive statistics of standard errors from the estimations for the two parameters.

$85 \%$ of our investors have loss aversion coefficients greater than 1 , which implies that they are loss averse ( 1 indicates that a loss or gain of the same value have an impact of the same magnitude on their utility). The mean (3.73) and median (1.93) values of the loss aversion coefficient indicate skewness to the right. The mean estimated annual discount rate is $7.7 \%$, and the median is $5.28 \%$. By comparison, the estimations of Dimmock and Kouwenberg (2010), based on the full reference point adjustment model of Loewenstein (1988), give mean and median values for the loss aversion coefficients which are higher (mean 5.61; median 2.47), and estimated discount rates which are lower (mean 5\%; median 4\%), than our estimations. Dimmock and Kouwenberg (2010) who use the same dataset, however, include all individuals in the panel rather than restricting their sample to investors only. Thus the differing results for the present study and for that of Dimmock and Kouwenberg (2010) suggest that investors have lower loss aversion coefficients and higher discount rates than the population as a whole. Our estimations are consistent with Tversky and Kahneman (1992) who find that individuals have a loss aversion coefficient of 2.25. We check whether loss aversion is highly correlated with both evaluation and rebalancing frequencies in order to rule out the possible selection effect of loss aversion on myopic behaviour. We find that correlations between loss aversion and myopia variables are rather weak. The correlation coefficient between loss aversion and evaluation frequency is 0.07 . The 
correlation coefficient between loss aversion and rebalancing frequency is greater at 0.33 but significant only at the $10 \%$ level.

\section{Other Psychological Variables}

We include questions enabling us to determine individuals' subjective time preferences and reference points following the approach of Veld-Merkoulova (2011) as shown in Table 4.

[Table 4 here]

Investors' time preferences indicate whether they are short-term or long-term oriented in planning for the future. Balduzzi and Lynch (1999) and Lynch and Balduzzi (2000) argue that long-term oriented investors are inclined to invest a greater proportion of their wealth in stocks than short-term oriented investors. We include a measure of investors' time preferences in order to examine the independent effect of myopia. To measure investors' time preference, we select a question from the DHS which identifies the extent to which individuals agree with a statement of "I often work on things that will only pay off in a couple of years". Individuals choose an answer on a Likert scale from 1 (totally disagree) to 7 (totally agree).

Based on the median value, we divide individuals who respond on scales 1 to 3 into the short-term oriented group (43\%) and those individuals who respond on scales 4 to 7 into the long-term oriented group (57\%).

In Table 4, we also present summary statistics for reference points (see detailed discussion in Veld and Veld-Merkoulova, 2008). The reference point to which an individual compares her investment returns is the most important element of the valuation stage of prospect theory (Kahneman and Tversky, 1979; Tversky and Kahneman, 1992). Thaler et al. (1997) argue that the reference point strongly influences investors' perceptions. When subjects perceive only positive returns from the market under conditions of high inflation, 
they increase their investment in risky assets without realising that they are suffering from money illusion (Shafir, Diamond, and Tversky, 1997). We offer respondents a choice of reference points including the initial price paid, returns on a savings account, the market index return, and other benchmarks. 57\% indicate that they check whether their investments have increased in value based on the price paid; around $30 \%$ compare with the returns on the savings account; only $8 \%$ consider whether their investments outperform market indices, such as the AEX in the Netherlands while 5\% refer to other benchmarks. The number of individuals who choose the market index is unexpectedly low, while the majority select the initial price paid as their reference point, thus supporting Samuelson and Zeckhauser (1988) and Shefrin and Statman (1985).

\section{Empirical Results}

\section{The Effects of MLA on the Investment Level}

We investigate the joint effects of myopia, loss aversion and control variables on the proportion of investors' total financial assets invested in equities. We apply the following equation model (1) and estimate Prais-Winsten (1954) regressions with panel-corrected standard errors (PCSE), after carrying out a Woodridge (2002) test to detect autocorrelations in the disturbances ${ }^{12}$.

$$
\begin{gathered}
\text { Equity }_{\mathrm{i}, \mathrm{t}}=\alpha+\mathrm{x}_{\mathrm{i}}^{\prime} \beta+\mathrm{y}_{\mathrm{i}, \mathrm{t}}^{\prime} \gamma+\mathrm{z}_{\mathrm{t}}^{\prime} \delta+\varepsilon_{\mathrm{i}, \mathrm{t}} \\
N\left(0, \sigma^{2}\right)
\end{gathered}
$$

The dependent variable Equity $y_{i t}$ denotes the observed proportion of equities in the total financial assets (in decimals) of individual $i$ at time $t(1997-2010) . \mathrm{x}_{\mathrm{i}}^{\prime}$ is the vector of investors' time-invariant characteristics including myopia variables, loss aversion, discount

\footnotetext{
${ }^{12}$ Based on simulation results, Drukker (2003) further suggests that the autocorrelation test of Wooldridge (2002) has robust properties with regard to its size and power when the sample size is reasonable.
} 
rates, time-preference, reference points, gender, marital status, education level, and employment status. $\mathrm{y}^{\prime}{ }_{\mathrm{i}, \mathrm{t}}$ is the vector of time-varying characteristics which includes age, financial assets, and debt ratio. $\mathrm{z}_{\mathrm{t}}^{\prime}$ is a vector of year dummies, which applies to all individuals. By including year dummies, we account for year specific effects such as macroeconomic conditions. $\varepsilon_{\mathrm{i}, \mathrm{t}}$ is a normally distributed error term which is corrected for the presence of arbitrary heteroskedasticity and serial correlation. Variable definitions are presented in Appendix A.

We present five specifications of empirical model (1) in Table 5. Regression (1) is the base model that examines the relation between MLA and the levels of equity investment after controlling for other demographical and financial characteristics. Regression (2) includes the discount rate, regression (3) includes the time preference variable, and regression (4) is estimated by including reference points within regression (1). Finally, regression (5) includes all explanatory and control variables.

\section{[Table 5 here]}

We include the variables for myopia and loss aversion independently, as well as the interactions between them. To avoid the dummy variable trap, we omit HEHR (high evaluation frequency with high rebalancing frequency) as a reference category. When we consider the coefficient estimates for myopia variables alone, investors with a low level of rebalancing frequency (the HELR, and in particular, the LELR groups) invest significantly less than more myopic investors with a high rebalancing frequency (HEHR category). There is no significant difference between the varying levels of evaluation frequency given the same level of rebalancing frequency (LEHR compared to HEHR and LELR compared to HELR). It is particularly important for our purpose to identify whether or not the coefficients for loss aversion differ across groups with higher or lower evaluation and/or rebalancing frequencies. 
For the HEHR group, higher loss aversion is associated with significantly lower equity investments (coefficient of -0.004). Taking into account interaction terms, we find that for all other investor groups, the loss aversion coefficient is not statistically significant. Thus investors with higher loss aversion hold a lower share of their wealth in stocks, but this applies only to investors who both evaluate and rebalance their portfolios frequently (HEHR group).

To interpret our finding of the negative association between a combination of frequent evaluation/rebalancing and high loss aversion, on one hand, and low investment in equities, on the other hand, we note that using non-experimental data prevent us from unequivocally interpreting this result as a causal effect of MLA on equity investments. Instead, there are three different possible interpretations of such correlations: 1) support for the theoretical predictions of the Benartzi and Thaler (1995) model; 2) reverse causality; and 3) existence of some unobserved variables (for example, personality traits) responsible for both types of behaviour. Of these three alternatives, reverse causality (the feedback from equity investment holdings to the frequency of evaluation/rebalancing) seems to be the least plausible explanation for our results. Normally, we would expect that investors with higher levels of equity holdings would evaluate/rebalance their portfolios more often, which is contrary to the negative correlations that we find. However, we cannot rule out that, even after carefully controlling for all available demographic, financial and psychological variables, there might be some underlying, unobserved, variables (such as personality traits) that drive both MLA and the tendency to invest in stocks. For this reason, our finding that empirical evidence on MLA among individual investors is consistent with the theoretical predictions of Benartzi and Thaler (1995) should be interpreted in conjunction with experimental studies that are free from this problem. 
With regard to the measurement of myopia, neither frequent evaluation of investment results nor frequent rebalancing taken separately appear to systematically increase the effect of loss aversion on investors' portfolio holdings. For example, the differences between loss aversion effects for HEHR versus LEHR, and for HELR versus LELR groups are small and not statistically significant as shown by the Wald tests in Table 5. We conclude that it is the combination of rebalancing and evaluation frequencies which causes the MLA effect. Our results are consistent with the strong interaction effect between rebalancing and evaluation frequencies, as identified by Langer and Weber (2008) in a controlled experimental setting.

We do not observe any specific effects from either investors' discount rates or time preferences on their equity holdings. In particular, inclusion of these variables has no material influence on MLA. Considerable disparities are observed to arise from investors' different reference points. As compared with those who choose market index as a reference point, investors who choose other reference points invest significantly less in stocks. Investors who compare their performance to the initial price paid have the lowest equity holding.

In terms of our control variables, our results do not indicate a significant gender effect, supporting Haliassos and Bertaut (1995). We observe a positive relationship between age and equity investments, although only at the $10 \%$ significance level, with older investors holding a higher proportion of equity investments. Van Rooij et al. (2011) and Hurd (1990) point out that this may be due to the different mortality rates of richer and poorer households, i.e. rich people tend to live longer. Our results, however, are inconsistent with the life-cycle theory of Cocco et al. (2005) and more specifically, with their argument that the level of optimal investment in risky assets decreases with investors' age. Given that, however, most Dutch investors are entitled to generous state pension ("AOW") benefits as well as to mandatory supplementary occupational pension arrangements, older investors may be less averse to 
holding risky portfolios. This may explain why such individuals hold a relatively higher proportion of equities than do younger Dutch investors.

We observe significant and negative effects from the marital status of investors, similar to those identified by Barber and Odean (2000; 2001), although only at the $10 \%$ significance level. We observe a significant education effect; contrary to our a priori expectations, however, we observe that those investors with college or university degrees invest significantly smaller proportions of their financial portfolios in equities than do other investors. These results may indicate that individuals' education levels are distinct from their levels of financial literacy as discussed in Van Rooij et al. (2011;2012).

Self-employed and retired individuals invest at significantly higher levels in stocks than individuals in regular employment. Our finding is consistent with Barsky et al. (1997), who argue that self-employed people are more risk tolerant and thus invest more in risky assets ${ }^{13}$. Self-employed individuals in the Netherlands can arrange individual pension provisions which supplement their state pension (AOW) benefits. Although such individuals can defer tax on the additional pension contributions made, they do not enjoy the benefit of employer contributions (Alessie et al. 2000). In addition, their uncertain personal income streams make it harder for them to contribute on a regular basis to pension plans. Therefore, self-employed individuals have a strong incentive to generate sufficient funds for retirement purposes. They may be more prepared to accept higher risk in the expectation of greater reward. $^{14}$

The total amount of financial assets is not significantly related to proportion of equity investments. The effect of the debt ratio on the proportion of equity investment is, however,

\footnotetext{
${ }^{13}$ Using US data, Heaton and Lucas (2000) argue that self-employed investors hold greater amounts of equity in their own businesses, but comparably little common stock. We exclude any equity holdings in self-employed individuals' own businesses; thus our finding cannot be explained by the argument of Heaton and Lucas (2000).

${ }^{14}$ Self-employed households and couples over 65 years old were also the wealthiest demographic groups in the Netherlands in 2009. More information is available at: http://www.cbs.nl/en-GB/menu/themas/inkomenbestedingen/publicaties/artikelen/archief/2010/2010-3011-wm.htm
} 
positive and significant, possibly reflecting greater risk tolerance among more leveraged households. This finding is consistent with that of Heaton and Lucas (2000) who suggest that some stocks are indirectly financed by mortgage debt. Consequently, a higher mortgage is associated with higher stock holding. Correspondingly, Alessie et al. (2000) report that in 1999 , only $40 \%$ of new mortgages in the Netherlands were issued to purchase first homes, the rest were issued to individuals to invest in second homes, or to finance stock market operations.

We observe significant year effects, which reflect high fluctuations in investors' equity holdings over time. Taking 1997 as a reference year, we also measure the effect of the 2008 financial crisis as presented in Table 5. Through comparing the average values of preand post-crisis time dummy variable coefficients, we observe that investors' investment fell significantly after the crisis, based on the Wald test.

\section{The Effect of MLA on Changes in Investment Levels Over Time}

In this section we investigate the relationship between MLA and the yearly changes in the individual investors' equity investment. In order to address dynamic effects, we control for the lagged changes in individuals' equity holding. To this end, we develop a structural state dependence model which includes a lagged dependent variable.

Changes in equity holding are also influenced by unobserved variables in our model, which would cause serial correlations if the initial conditions were unaccounted for. Thus we include as initial conditions in our model, individuals' equity investment levels at the beginning of the observation period, as suggested by Wooldridge (2005).

$$
\begin{gathered}
\Delta \text { Equity }_{\mathrm{i}, \mathrm{t}+1}=\alpha_{1} \Delta \text { Equity }_{\mathrm{i}, \mathrm{t}}+\alpha_{2} \text { Equity }_{\mathrm{i}, \mathrm{t}}+\mathrm{x}_{\mathrm{i}}^{\prime} \beta+\Delta \mathrm{y}_{\mathrm{i}, \mathrm{t}}^{\prime} \gamma+\mathrm{z}_{\mathrm{t}}^{\prime} \delta+\varepsilon_{\mathrm{i}, \mathrm{t}} \\
N\left(0, \sigma^{2}\right)
\end{gathered}
$$

In equation (2) above, $\Delta$ Equity $_{\mathrm{i}, \mathrm{t}+1}$, the dependent variable (in decimals), denotes the changes in the equity portfolio weight of an individual $i$ over time $t$ (1997-2010). The 
dependent variable has a minimum value of -1 and a maximum value of 1 , while most observations are concentrated around zero. The lagged dependent variable, $\Delta E q u i t y_{\mathrm{i}, \mathrm{t}}$, and initial investment level, Equity $_{\mathrm{i}, \mathrm{t}}$, are included as covariates as discussed above. The rest of the variables are the same as in equation (1), and we also control for heteroskedasticity and autocorrelations in the disturbances. We present five regression model specifications in Table 6.

\section{[Table 6 here]}

For all specifications in Table 6, the lagged dependent variable is significantly and negatively correlated with the dependent variable while initial investment levels are significantly and positively correlated with it. The negative autocorrelation of the changes in investment level in equities reflects individual investors' responses to volatile market changes during the sample period. Even if investors are aware that market returns exhibit the tendency of mean reversion, they may suffer from 'gambler's fallacy' (Tversky and Kahneman, 1971). According to this notion, gamblers often bet on a fair chance, perceiving a random sequence as reflecting true probabilities. If the sequence consistently favours one direction, they expect the next will exhibit the opposite tendency, i.e. a random process will self-correct. Thus, investors make changes to their equity holdings in the direction opposite to that of the preceding change.

Most of the other control variables either exhibit expected signs or have little effect on the changes in equity investment levels. Investor age has a negative relationship with changes in equity holdings. Although older investors hold higher proportion of equities, they reduce their holdings over time, supporting the life-cycle theory of Cocco et al. (2005). Marital status also plays a significantly positive role in the changes in equity holdings, supporting the argument of Agnew et al. (2003) that stock allocations should be higher for married investors since two earners within a household enable greater potential for diversification. We observe 
no significant education effect. Those investors who select returns on the savings account as their reference point increase their level of equity investments to a greater extent (significant at the $10 \%$ level) than investors with a reference point of market return. Decreasing equity investments are exhibited by self-employed individuals as compared to regular employees. The equity portfolio weights tend to increase with investors' financial assets, but not with their debt ratios. The significant Wald test statistics in Table 6, which compare the average values of pre- and post-crisis time dummy coefficients taking 1999 as a reference year, suggest that investors increased their equity holdings following the 2008 financial crisis.

With regard to the effects of myopia, we observe that investors with low evaluation frequency increase their equity investments over time, as indicated by the difference in coefficients between HEHR and LELR, as well as between HELR and LELR (as shown by the significant Wald test statistics in Table 6). At the same time, coefficient estimates for either loss aversion or for the interaction between myopia and loss aversion are not statistically significant. Thus our results indicate that, regardless of their loss aversion, investors who evaluate their portfolios less frequently increase their equity investments over time. However, it appears that most of the MLA effect is already included on investment level, and that further changes in investors' portfolio allocations are not associated with MLA.

\section{Redefining Investment Level Changes}

As Bilias, Georgarakos and Haliassos (2010) note, widespread portfolio inertia means that more than half of households do not trade stocks in their portfolios for extended periods of time. In many cases, investors do not actively rebalance their portfolios, but rather follow a passive buy-and-hold strategy. However, as the values of their equity holdings change due to market fluctuations, this automatically affects their investments. In order to avoid treating such changes as deliberate investment decisions, we control for the impact of market returns. 
We test whether MLA is associated with the changes in equity holdings made by investors solely as a result of active trading, by excluding the changes made passively due to market movements. We estimate the following regression equation (3) which is the same as equation (2) except for the redefined dependent variable.

$$
\begin{aligned}
& \text { D. Equity }{ }_{\mathrm{i}, \mathrm{t}}=\alpha_{1} \text { D. Equity }_{\mathrm{i}, \mathrm{t}-1}+\alpha_{2} \text { Equity }_{\mathrm{i}, \mathrm{t}}+\mathrm{x}_{\mathrm{i}}^{\prime} \beta+\Delta \mathrm{y}_{\mathrm{i}, \mathrm{t}}^{\prime} \gamma+\mathrm{z}_{\mathrm{t}}^{\prime} \delta+\varepsilon_{\mathrm{i}, \mathrm{t}} \\
& \text { D. } \text { Equity }_{\mathrm{i}, \mathrm{t}}=\text { Equity }_{\mathrm{i}, \mathrm{t}}-\text { Equity }_{\mathrm{i}, \mathrm{t}}^{*} \\
& \text { Equity }_{\mathrm{i}, \mathrm{t}}^{*}=\frac{\text { Equity }\left(1+\mathrm{r}_{\mathrm{t}}\right)}{\text { Equity }\left(1+\mathrm{r}_{\mathrm{t}}\right)+\text { Other Financial Assets }} \\
& r_{t}=\frac{\mathrm{AEXI}_{t}-\mathrm{AEXI}_{\mathrm{t}-1}}{\mathrm{AEXI}_{\mathrm{t}-1}}
\end{aligned}
$$

Firstly, we obtain yearly market returns $r_{t}$ from the AEX Total Return Index, and then calculate investors' 'expected' equity holdings (Equity*) at time $t$ through adjusting their investment levels at time $t-1$ by the market return of $r_{\mathrm{t}}$. From the reported values of individuals' equity holdings at time $t$, we subtract the estimated Equity* value at time $t$, to obtain the changes made by investors, D. Equity $y_{\mathrm{i}, \mathrm{t}}$. If investors do not actively change their equity holdings, D.Equity $y_{\mathrm{i}, \mathrm{t}}$ should equal zero, on average. We report five specifications of the regression model in Table 7.

[Table 7 here]

The coefficients for LEHR and LELR are all positive, and statistically significant. This suggests that changes in the equity investments are positively related to the low level of evaluation frequency, supporting our previous findings. Coefficients for loss aversion and its interactions with myopia remain not significantly different from zero. Our robustness check confirms that, regardless of loss aversion, infrequent evaluation positively affects investment level changes, supporting the findings of Bellemare et al. (2005). With regard to other control variables, most relationships are similar to those shown in Table 6 . Thus we can confirm that 
redefining the dependent variable by controlling for the impact of market return on the changes of investors' equity holdings over time does not influence our results.

\section{Summary and Conclusions}

We investigate whether myopic loss aversion as defined by Benartzi and Thaler (1995) is correlated with individual investors' portfolio allocation decisions. While MLA has been studied previously in a laboratory setting, our study is the first to examine the relationship between MLA and individual investment portfolios using real-life data. Following Langer and Weber (2008), we disentangle the effects of evaluation frequency from those of rebalancing frequency. The measures of myopia are combined with individuals' loss aversion, which we estimate from their responses to the hypothetical intertemporal choice questions developed by Thaler (1981) and Loewenstein (1988).

We observe that the combination of high rebalancing frequency with loss aversion has significant negative correlation with individuals' equity investments. While establishing causality is difficult for the actual investment data, this result is consistent with the main prediction of the MLA theory of Benartzi and Thaler (1995). Among highly loss averse individuals, only those, who both evaluate and rebalance their portfolios frequently, invest relatively little in equities. This result supports the experimental findings of Langer and Weber (2008) on the interaction between portfolio evaluation and rebalancing. When we further investigate changes in investors' investments in stocks over time, infrequent portfolio evaluation is associated with an increase in their equity holdings, but loss aversion has no effect. This result is robust to controlling for the impact of market returns on individuals' asset values.

Overall, we find that the widespread existence of MLA is associated with the financial decision-making of individuals. Those investors, who are highly loss averse and frequently 
evaluate investment performance and rebalance investment portfolios, tend to have low equity holdings in their financial portfolios, which is likely to lead to utility losses over investors' lifetimes. However, once individuals establish their portfolio allocations according to their levels of both loss aversion and myopia, myopic loss aversion is no longer associated with further decreases in their levels of equity investments. Our results support the suggestion that long-term investment vehicles (such as defined contribution pension funds) should offer default asset allocations with higher proportions of equities in order to provide potential for more gains from the market participation across a broader range of investors. 


\section{References}

Agnew, J., Balduzzi, P., and Sundén, A., 2003, "Portfolio Choice and Trading in a Large 401(k) Plan", American Economic Review, vol.93, no.1, pp.193-215.

Alessie, R. J. M., Hochguertel, S., and van Soest, A., 2002, "Household Portfolios in the Netherlands", in L. Guiso, M. Haliassos, and T. Jappelli (eds.) Household Portfolios. Cambridge, MA: MIT Press, 340-388.

Alessie, R.J.M., Hochguertel, S., and van Soest, A., 2004, "Ownership of Stocks and Mutual Funds: A Panel Data Analysis”. Review of Economics and Statistics, vol.86, no.3, pp.83-796.

Ang, A., Bekaert, G., and Liu, J., 2005, "Why stocks may disappoint", Journal of Financial Economics, vol.76, no.3, pp.471-508.

Balduzzi, P., and Lynch, A. W., 1999, "Transaction Costs and Predictability: Some Utility Cost Calculations", Journal of Financial Economics, vol.52, no.1, pp.47-78.

Barber, B. M., and Odean, T., 2000, “Trading Is Hazardous to Your Wealth: The Common Stock Investment Performance of Individual Investors", Journal of Finance, vol.55, no.2, pp.773-806

Barber, B. M., and Odean, T., 2001, "Boys Will be Boys: Gender, Overconfidence, and Common Stock investment", Quarterly Journal of Economics, vol.116, no.1, pp.261-292

Barsky, R. B., Juster, F. T., Kimball, M. S., and Shapiro, M. D., 1997, "Preference Parameters and Behavioral Heterogeneity: An Experimental Approach in the Health and Retirement Study," Quarterly Journal of Economics, vol.112, no.2, pp.537-579.

Bellemare, C., Krause, M., Kröger, S., and Zhang, C., 2005, "Myopic loss aversion: Information feedback vs. investment flexibility", Economics Letters, vol.87, no.3, pp.319-324.

Benartzi, S. and Thaler, R. H., 1995, "Myopic Loss Aversion and the Equity Premium Puzzle”, Quarterly Journal of Economics, vol.110, no.1, pp.73-92.

Bilias, Y., Georgarakos, D., and Haliassos, M., 2010, "Portfolio inertia and stock market fluctuations", Journal of Money, Credit and Banking, vol. 42, no. 4, pp. 715-742.

Cocco, J. F., 2004, "Portfolio Choice in the Presence of Housing", Review of Financial Studies, vol.18, no.2, pp.535-567.

Cocco, J. F., Gomes, F. J., and Maenhout, P. J., 2005, "Consumption and portfolio choice over the life cycle", Review of Financial Studies, vol.18, no.2, pp.491-533.

Dimmock, S. G., and Kouwenberg, R., 2010, "Loss-Aversion and Household Portfolio Choice”, Journal of Empirical Finance, vol.17, no.3, pp.441-459.

Dong, M., Robinson, C., and Veld, C., 2005, "Why individual investors want dividends", Journal of Corporate Finance, vol.12, no.1, pp.121-158. 
Drukker, D. M., 2003, "Testing for serial correlation in linear panel-data models", Stata Journal, vol.3, no.2, pp.168-177.

Eriksen, K. W., and Kvaløy, O., 2010, "Do financial advisors exhibit myopic loss aversion?”, Financial Markets and Portfolio Management, vol.24, issue 2, pp.159-170.

Fellner, G., and Sutter, M., 2009, "Causes, Consequences, and Cures of Myopic Loss Aversion - An Experimental Investigation”, Economic Journal, vol.119, pp.900-916.

Gneezy, U., Kapteyn, A., and Potters, J., 2003, "Evaluation periods and asset prices in a market experiment”, Journal of Finance, vol.58, no.2, pp.821-838.

Gneezy, U., and Potters, J., 1997, "An Experiment on Risk Taking and Evaluation Periods", Quarterly Journal of Economic, vol.112, issue 2, pp.631-645.

Guiso, L., Sapienza, P., and Zingales, L., 2008, “Trusting the Stock Market", Journal of Finance, vol.63, no.6, pp.2557-2600.

Gul, F., 1991, “A theory of disappointment aversion”, Econometrica, vol.59, no.3, pp.667686.

Haigh, M. S., and List, J. A., 2005, "Do professional traders exhibit myopic loss aversion? An experimental analysis", Journal of Finance, vol.60, no.1, pp.523-534.

Haliassos, M., and Bertaut, C., 1995, "Why do so few hold stocks?", Economic Journal, vol.105, no.432, pp.1110-1129.

Heaton, J., and Lucas, D., 2000, "Portfolio choice and asset prices: The importance of entrepreneurial risk", Journal of Finance, vol.55, no.3, pp.1163-1198.

Hurd, M. D., 1990, "Research on the Elderly: Economic Status, Retirement, and Consumption and Saving", Journal of Economic Literature, vol.28, no.2, pp.565-637.

Kahneman, D., and Tversky, A., 1979, "Prospect Theory: An Analysis of Decision Under Risk", Econometrica, vol.47, no.2, pp.363-391.

Kliger, D., and Levit, B., 2009, "Evaluation periods and asset prices: Myopic loss aversion at the financial marketplace", Journal of Economic Behaviour \& Organization, vol.71, issue 2, pp.361-371.

Langer, T., and Weber, M., 2008, "Does commitment or feedback influence myopic loss aversion? An experimental analysis", Journal of Economic Behaviour \& Organization, vol.67, issues 3-4, pp.810-819.

Loewenstein, G., 1988, "Frames of Mind in Intertemporal Choice", Management Science, vol.34, no.2, pp.200-214.

Loewenstein, G., and, Prelec, D., 1992, "Anomalies in Intertemporal Choice: Evidence and an interpretation”, Quarterly Journal of Economics, vol.107, no.2, pp.573-597. 
Lynch, A. W., and Balduzzi, P., 2000, "Predictability and Transaction Costs: The Impact on Rebalancing Rules and Behavior”, Journal of Finance, vol.55, no.5, pp.2285-2309.

Mehra, R., and Prescott, E. C., 1985, “The Equity Premium: A Puzzle”, Journal of Monetary Economics, vol.15, no.2, pp.145-161.

Odean, T., 1999, “Do investors trade too much?”, American Economic Review, vol.89, no.5, pp.1279-1298.

Prais, S. J., and Winsten, C. B., 1954, “Trend estimators and serial correlation, Working paper 383, Cowles Commission.

Read, D., Loewenstein, G., and Rabin, M., 1999, "Choice bracketing", Journal of Risk and Uncertainty, vol.19, issues 1-3, pp.171-197.

Samuelson, W., and Zeckhauser, R., 1988, "Status Quo Bias in Decision Making”, Journal of Risk and Uncertainty, vol.1, issue 1, pp.7-59.

Shafir, E., Diamond, P., and Tversky, A., 1997, "Money illusion", Quarterly Journal of Economics, vol.112, no.2, pp.341-374.

Shefrin, H., and Statman, M., 1985, “The Disposition to Sell Winners Too Early and Ride Losers Too Long: Theory and Evidence”, Journal of Finance, vol.40, no.3, pp.777-792.

Thaler, R.H., 1981, "Some Empirical Evidence on Dynamic Inconsistency", Economics Letters, vol.8, issue 3, pp.201-207.

Thaler, R. H., Tversky, A., Kahneman, D., and Schwartz, A., 1997, “The effect of myopia and loss aversion on risk taking: An experimental test", Quarterly Journal of Economics, vol.112, no.2, pp.647-661.

Tu, Q., 2004, "Reference Points and Loss Aversion in Intertemporal Choice", Working Paper, Available at SSRN: http://ssrn.com/abstract=644142.

Tversky, A., and Kahneman. D., 1971, "Belief in the Law of Small Numbers", Psychological Bulletin, vol.76, no.2, pp.105-110.

Tversky, A., and Kahneman, D., 1992, "Advances in prospect theory: cumulative representations of uncertainty”, Journal of Risk and Uncertainty, vol.5, no.4, pp.297-323.

Van Rooij, M., Lusardi, A., and Alessie, R., 2011, "Financial Literacy and Stock Market Participation”, Journal of Financial Economics, vol.101, issue 2, pp.449-472.

Van Rooij, M., Lusardi, A., and Alessie, R., 2012, "Financial Literacy, Retirement Planning and Household Wealth", Economic Journal, vol.122, issue 560, pp.449-478.

Veld, C., and Veld-Merkoulova, Y., 2008, "The risk perceptions of individual investors", Journal of Economic Psychology, vol.29, issue 2, pp.226-252. 
Veld-Merkoulova, Y., 2011, "Investment horizon and portfolio choice of private investors", International Review of Financial Analysis, vol.20, issue 2, pp.68-75.

Wooldridge, J. M., 2002, Econometric Analysis of Cross Section and Panel Data, Cambridge, MA: MIT Press.

Wooldridge, J. M., 2005, "Simple Solutions to the Initial Conditions Problems in Dynamic, Nonlinear Panel Data Models with Unobserved Heterogeneity", Journal of Applied Econometrics, vol.20, issue 1, pp.39-54. 
Table 1 Sampling Process and Demographic Background

Panel A - Sampling Process

The following table presents the sampling process of this study.

\begin{tabular}{lll}
\hline & Remained & Lost \\
\hline Total number of individuals contacted on behalf of our survey & 2,226 & - \\
Individuals who were able to answer investment related questions in our survey & 687 & 1,539 \\
After merging the dataset with the hypothetical intertemporal questions & 407 & 280 \\
After merging the dataset with the time preference question & 403 & 4 \\
After merging the dataset with questions on assets and liabilities & $\mathbf{4 0 0}$ & 3 \\
\hline
\end{tabular}

\section{Panel B - Demographic Background of Individual Investors}

The following table presents the demographic backgrounds of 400 individuals in our sample.

\begin{tabular}{llrllr}
\hline Gender & Men & $68.3 \%$ & Education & Secondary Education & $43.3 \%$ \\
& Women & $31.8 \%$ & & College or University & $56.8 \%$ \\
\multirow{3}{*}{ Marital status } & & & & \\
& & & & & \\
& Single & $20.5 \%$ & Occupation & Regular employment & $54.8 \%$ \\
& Married & $79.5 \%$ & & Self-employed & $12.8 \%$ \\
& & & Retired & $24.5 \%$ \\
& $30 \mathrm{~s}$ and Less & $20.3 \%$ & Others & \\
& $40 \mathrm{~s}$ & $26 \%$ & & \\
& $50 \mathrm{~s}$ & $21.3 \%$ & & \\
& $60 \mathrm{~s}$ & $17.5 \%$ & &
\end{tabular}

\section{Panel C - Financial Information}

The following table presents the ownership rate, defined as the percentage of individuals who hold equities, and descriptive statistics of the proportion of equity holdings from individuals' total financial assets, and its breakdown between shares and mutual funds. The AEX index total return is the average annual return over the sample period, including reinvested dividends.

\begin{tabular}{cc|r|r|rr|r}
\hline & Stats. & Ownership \% & Equities \% & Mutual funds \% & Share \% & $\begin{array}{c}\text { AEX } \\
\text { Return }\end{array}$ \\
\hline Mean & $59.39 \%$ & $23.38 \%$ & $59.78 \%$ & $39.18 \%$ & $8.45 \%$ \\
Median & & $6.95 \%$ & $85.39 \%$ & $12.19 \%$ & \\
Std. Dev & & $29.68 \%$ & $43.94 \%$ & $43.55 \%$ & \\
\hline \hline
\end{tabular}




\section{Table 2 Measuring the Level of Myopia}

\section{Evaluation Frequency}

How often do you evaluate the performance of your stock portfolio on average? An evaluation can take different forms. It can, for example, vary from including recent prices in a spreadsheet to simply checking in newspapers or on teletext how the shares perform.

\begin{tabular}{|l|r|r|r|r|r|r|r|}
\hline Frequency & Daily & Weekly & Monthly & Quarterly & Annually & Less often & Total \\
\hline $\mathrm{N}$ & 52 & 62 & 63 & 87 & 87 & 49 & 400 \\
$(\%)$ & $(13 \%)$ & $(15.5 \%)$ & $(15.8 \%)$ & $(21.8 \%)$ & $(21.8 \%)$ & $(12.3 \%)$ & $(100 \%)$ \\
\hline \multicolumn{3}{|r|}{ High Level (44\%) } & \multicolumn{3}{|c|}{ Low Level (56\%) } & \\
\hline
\end{tabular}

\section{Rebalancing Frequency}

How often do you change your stock portfolio by buying or selling shares without the need for cash?

\begin{tabular}{|c|c|c|c|c|c|c|c|}
\hline Frequency & Daily & Weekly & Monthly & Quarterly & Annually & Less often & Total \\
\hline $\begin{array}{l}\mathrm{N} \\
(\%)\end{array}$ & $\begin{array}{r}1 \\
(0.3 \%)\end{array}$ & $\begin{array}{r}6 \\
(1.5 \%)\end{array}$ & $\begin{array}{r}21 \\
(5.3 \%)\end{array}$ & $\begin{array}{r}38 \\
(9.5 \%)\end{array}$ & $\begin{array}{r}54 \\
(13.5 \%)\end{array}$ & $\begin{array}{r}280 \\
(70 \%)\end{array}$ & $\begin{array}{r}400 \\
(100 \%)\end{array}$ \\
\hline & \multicolumn{5}{|c|}{ High Level (30\%) } & Low Level (70\%) & \\
\hline
\end{tabular}

Groupings by the level of Myopia

\begin{tabular}{lrr}
\hline & Frequency & Per cent \\
\hline HEHR (High Evaluation with High Rebalancing frequency) & 70 & $17.5 \%$ \\
HELR (High Evaluation with Low Rebalancing frequency) & 107 & $26.8 \%$ \\
LEHR (Low Evaluation with High Rebalancing frequency) & 50 & $12.5 \%$ \\
LELR (Low Evaluation with Low Rebalancing frequency) & 173 & $43.3 \%$ \\
Total & 400 & $100 \%$ \\
\hline
\end{tabular}


Table 3 Measuring Loss Aversion Coefficients and Discount Rates

\section{Panel A - Intertemporal Choice Questions}

Descriptive statistics for eight hypothetical intertemporal decision questions of 400 individuals are presented below. These questions specify delaying vs. speeding-up a payment; gains vs. losses; payment size of $f 1000$ vs. $f 100,000$ in Dutch guilders with a time dimension of one year. The gains are from winning a prize in the National lottery situation and the losses are from a tax assessment. The delayed premium cost is a compensation for the delayed consumption compared to the immediate consumption, and the speeding-up cost is a sacrifice to advance the delayed consumption to immediate consumption.

\begin{tabular}{|l|r|r|r|r|r|}
\hline \multicolumn{1}{|c|}{ Questions } & \multicolumn{1}{c|}{ Mean } & Median & Std. Dev & Min & Max \\
\hline \% of Premium for Delay of Gain, $f 1,000$ & $17.82 \%$ & $11.11 \%$ & $17.012 \%$ & $0 \%$ & $100 \%$ \\
\hline \% of Premium for Delay of Gain, $f 100,000$ & $12.99 \%$ & $7.94 \%$ & $14.20 \%$ & $0 \%$ & $97 \%$ \\
\hline$\%$ of Cost for Delay of Loss, $f 1,000$ & $3.06 \%$ & $1.80 \%$ & $4.418 \%$ & $0 \%$ & $27 \%$ \\
\hline$\%$ of Cost for Delay of Loss, $f 100,000$ & $2.59 \%$ & $1.74 \%$ & $3.452 \%$ & $0 \%$ & $22 \%$ \\
\hline$\%$ of Sacrifice to Speed up of Gain, $f 1,000$ & $4.02 \%$ & $1.58 \%$ & $7.803 \%$ & $0 \%$ & $50 \%$ \\
\hline$\%$ of Sacrifice to Speed up of Gain, $f 100,000$ & $3.91 \%$ & $1.76 \%$ & $7.012 \%$ & $0 \%$ & $47 \%$ \\
\hline$\%$ of Reduction by Speed up of Loss, $f 1,000$ & $9.59 \%$ & $7.96 \%$ & $7.394 \%$ & $0 \%$ & $47 \%$ \\
\hline$\%$ of Reduction by Speed up of Loss, $f 100,000$ & $7.33 \%$ & $5.40 \%$ & $6.779 \%$ & $0 \%$ & $44 \%$ \\
\hline
\end{tabular}

Panel B - Estimation results of Loss-Aversion Coefficient and Discount Rate

\begin{tabular}{|l|r|r|r|r|r|}
\hline \multicolumn{1}{|c|}{ Parameters } & \multicolumn{1}{c|}{ Mean } & \multicolumn{1}{c|}{ Median } & \multicolumn{1}{c|}{ Std. Dev. } & \multicolumn{1}{c|}{ Min } & \multicolumn{1}{c|}{ Max } \\
\hline Loss Aversion Coefficient & 3.73 & 1.93 & 6.45 & 0.10 & 40.00 \\
\hline S.E. of Loss-Aversion & 2.14 & 0.42 & 8.89 & 0.00 & 139.66 \\
\hline Discount Rate & $7.7 \%$ & $5.28 \%$ & $7.00 \%$ & $0.00 \%$ & $100 \%$ \\
\hline S.E. of Discount Rate & $2.24 \%$ & $1.36 \%$ & $2.99 \%$ & $0.00 \%$ & $1.80 \%$ \\
\hline
\end{tabular}




\section{Table 4 Questions on Other Psychological Variables}

\section{Time Preference}

Do you agree with the statement?

"I often work on things that will only pay off in a couple of years".

\begin{tabular}{|c|c|c|c|c|c|c|c|c|}
\hline & $\begin{array}{c}\text { Strongly disagree } \\
1\end{array}$ & 2 & 3 & 4 & 5 & 6 & $\begin{array}{c}\text { Strongly agree } \\
7\end{array}$ & Tota \\
\hline $\begin{array}{l}\mathrm{N} \\
(\%)\end{array}$ & $\begin{array}{r}17 \\
(6.4 \%)\end{array}$ & $\begin{array}{r}41 \\
(15.5 \%)\end{array}$ & $\begin{array}{r}53 \\
(20 \%)\end{array}$ & $\begin{array}{r}51 \\
(19.2 \%)\end{array}$ & $\begin{array}{r}69 \\
(26 \%)\end{array}$ & $\begin{array}{r}25 \\
(9.4 \%)\end{array}$ & $\begin{array}{r}9 \\
(3.4 \%)\end{array}$ & $(100 \%)$ \\
\hline
\end{tabular}

\section{Reference Point}

When you evaluate the performance of your stock investments (including stocks in investment funds), what is your relevant benchmark?

\begin{tabular}{|l|r|r|r|r|r|}
\hline Categories & The price paid & Savings account & AEX index & \multicolumn{1}{l|}{ Other } & \multicolumn{1}{c|}{ Total } \\
\hline $\mathrm{N}$ & 227 & 118 & 34 & 21 & 400 \\
$(\%)$ & $(56.8 \%)$ & $(29.5 \%)$ & $(8.5 \%)$ & $(5.2 \%)$ & $(100 \%)$ \\
\hline
\end{tabular}




\section{Table 5 The Effect of MLA on the Investment Level}

The following table presents the results of Prais-Winsten regression of panel-corrected standard error (PCSE) estimates accounting for both heteroskedasticity and serial correlation of the disturbances. The dependent variable is the portfolio equity weight of an individual (in decimals). In our unbalanced panel, the total number of observations of non-zero risky financial assets is 1986 from 340 investors. Corrected $z$-statistics are in parentheses and the significance levels are denoted by asterisks, $* * * 1 \%, * * 5 \%$, and $* 10 \%$ (p-values are two-tailed).

\begin{tabular}{|c|c|c|c|c|c|c|c|c|c|c|}
\hline \multirow[b]{2}{*}{ Equity } & \multicolumn{2}{|c|}{ (1) } & \multicolumn{2}{|c|}{ (2) } & \multicolumn{2}{|c|}{ (3) } & \multicolumn{2}{|c|}{ (4) } & \multicolumn{2}{|c|}{ (5) } \\
\hline & Coef. & $\mathbf{z}$ & Coef. & $\mathbf{z}$ & Coef. & $\mathbf{z}$ & Coef. & $\mathbf{z}$ & Coef. & $\mathbf{z}$ \\
\hline HELR & $-0.053 * *$ & $(-1.93)$ & $-0.053 * *$ & $(-1.93)$ & $-0.057 * *$ & $(-2.08)$ & $-0.053^{*}$ & $(-1.91)$ & $-0.056 * *$ & $(-2.03)$ \\
\hline LEHR & 0.006 & $(0.16)$ & 0.005 & $(0.13)$ & 0.006 & $(0.15)$ & 0.007 & $(0.20)$ & 0.006 & $(0.16)$ \\
\hline LELR & $-0.080 * * *$ & $(-3.09)$ & $-0.080 * * *$ & $(-3.07)$ & $-0.083 * * *$ & $(-3.18)$ & $-0.074 * * *$ & $(-2.79)$ & $-0.076 * * *$ & $(-2.84)$ \\
\hline Loss Aversion (LA) & $-0.004 * *$ & $(-2.12)$ & $-0.004 * *$ & $(-1.93)$ & $-0.004 * *$ & $(-2.10)$ & $-0.004 * *$ & $(-2.21)$ & $-0.004 * *$ & $(-1.99)$ \\
\hline HELR*LA & $0.006^{* *}$ & $(1.98)$ & $0.005^{*}$ & $(1.80)$ & $0.006^{* *}$ & $(2.06)$ & $0.006 * *$ & $(2.15)$ & $0.006^{* * *}$ & (1.99) \\
\hline LEHR* LA & 0.001 & $(0.09)$ & 0.001 & $(0.12)$ & 0.000 & $(0.06)$ & 0.002 & $(0.21)$ & 0.002 & $(0.22)$ \\
\hline LELR* LA & $0.006 * *$ & (2.33) & $0.006 * *$ & $(2.10)$ & $0.006^{* *}$ & $(2.31)$ & $0.006 * *$ & $(2.41)$ & $0.006 * *$ & (2.15) \\
\hline Discount Rate & & & -0.076 & $(-0.65)$ & & & & & -0.092 & $(-0.79)$ \\
\hline Time Preference & & & & & -0.016 & $(-0.96)$ & & & -0.013 & $(-0.76)$ \\
\hline Reference Points: Initial Price & & & & & & & $-0.077 * * *$ & $(-2.50)$ & $-0.076 * * *$ & $(-2.49)$ \\
\hline Reference Points: Savings account & & & & & & & $-0.076^{* *}$ & $(-2.36)$ & $-0.073 * *$ & $(-2.24)$ \\
\hline Reference Points: Others & & & & & & & -0.076 & $(-1.46)$ & -0.074 & $(-1.42)$ \\
\hline Gender (Men) & 0.008 & $(0.36)$ & 0.008 & $(0.36)$ & 0.008 & $(0.38)$ & 0.011 & $(0.48)$ & 0.010 & $(0.47)$ \\
\hline Age & $0.002 *$ & (1.73) & $0.002 *$ & $(1.75)$ & $0.002^{*}$ & $(1.79)$ & 0.002 & $(1.54)$ & 0.002 & (1.61) \\
\hline Marriage & $-0.035^{*}$ & $(-1.69)$ & $-0.034 *$ & $(-1.66)$ & -0.033 & $(-1.60)$ & $-0.036^{*}$ & $(-1.77)$ & $-0.035^{*}$ & $(-1.68)$ \\
\hline Education & $-0.033^{*}$ & $(-1.82)$ & $-0.032 *$ & $(-1.80)$ & $-0.035^{*}$ & $(-1.91)$ & $-0.035^{* *}$ & $(-1.93)$ & $-0.036 * *$ & $(-1.98)$ \\
\hline Occupation: Self-employed & $0.135^{* * * *}$ & $(4.16)$ & $0.134 * * *$ & $(4.14)$ & $0.134 * * *$ & (4.15) & $0.141 * * *$ & $(4.38)$ & $0.139 * * *$ & (4.34) \\
\hline Occupation: Retired & $0.093^{* * *}$ & $(3.15)$ & $0.091 * * *$ & $(3.07)$ & $0.093 * * *$ & $(3.14)$ & $0.092 * * *$ & (3.13) & $0.089 * * *$ & (3.04) \\
\hline Occupation: Others & 0.030 & $(0.91)$ & 0.029 & $(0.88)$ & 0.033 & $(1.00)$ & 0.025 & $(0.76)$ & 0.026 & $(0.79)$ \\
\hline Financial Assets & 0.004 & $(0.63)$ & 0.004 & $(0.61)$ & 0.004 & $(0.62)$ & 0.003 & $(0.50)$ & 0.003 & $(0.47)$ \\
\hline Debt ratio & $0.013^{* *}$ & (1.98) & $0.013 * *$ & $(2.00)$ & $0.013 * *$ & (1.98) & $0.013 * *$ & (1.98) & $0.013^{* *}$ & (2.02) \\
\hline Year Effect & \multicolumn{2}{|c|}{ Significant } & \multicolumn{2}{|c|}{ Significant } & \multicolumn{2}{|c|}{ Significant } & \multicolumn{2}{|c|}{ Significant } & \multicolumn{2}{|c|}{ Significant } \\
\hline Constant & $0.406^{* * *}$ & $(7.16)$ & $0.410 * * *$ & $(7.22)$ & $0.413 * * *$ & $(7.25)$ & $0.484 * * *$ & (7.63) & $0.494 * * *$ & (7.75) \\
\hline AR(1) Rho & \multicolumn{2}{|c|}{0.637} & \multirow{2}{*}{\multicolumn{2}{|c|}{$\begin{array}{l}0.638 \\
0.215\end{array}$}} & \multirow{2}{*}{\multicolumn{2}{|c|}{$\begin{array}{l}0.637 \\
0.215\end{array}$}} & \multirow{2}{*}{\multicolumn{2}{|c|}{$\begin{array}{l}0.637 \\
0.218\end{array}$}} & \multirow{2}{*}{\multicolumn{2}{|c|}{$\begin{array}{l}0.636 \\
0.218\end{array}$}} \\
\hline R-Squared & \multicolumn{2}{|c|}{0.215} & & & & & & & & \\
\hline Wald Test & Chi2(1) & Prob. & Chi2(1) & Prob. & Chi2(1) & Prob. & Chi2(1) & Prob. & Chi2(1) & Prob. \\
\hline HEHR $*$ LA $=$ LEHR $*$ LA & 0.01 & 0.928 & 0.02 & 0.902 & 0.00 & 0.953 & 0.04 & 0.835 & 0.05 & 0.828 \\
\hline HELR $*$ LA $=$ LELR $*$ LA & 0.02 & 0.889 & 0.02 & 0.897 & 0.00 & 0.962 & 0.00 & 0.953 & 0.00 & 0.995 \\
\hline HEHR $*$ LA $=$ HELR $*$ LA & $3.93 * *$ & 0.047 & $3.25^{*}$ & 0.071 & $4.22 * *$ & 0.040 & $4.63 * *$ & 0.031 & $3.97 * *$ & 0.046 \\
\hline LEHR $*$ LA $=$ LELR $*$ LA & 0.45 & 0.501 & 0.33 & 0.565 & 0.49 & 0.483 & 0.33 & 0.563 & 0.25 & 0.618 \\
\hline HEHR $*$ LA $=$ LELR $*$ LA & $5.44 * * *$ & 0.019 & $4.42 * *$ & 0.036 & $5.33 * *$ & 0.021 & $5.81 * *$ & 0.016 & $4.61 * *$ & 0.032 \\
\hline Effect of the Crisis & $19.88^{* * *}$ & 0.000 & $19.89 * * *$ & 0.000 & $19.59 * * *$ & 0.000 & $19.19 * * *$ & 0.000 & $19.02 * * *$ & 0.00 \\
\hline Mean y1998-y2007 & \multirow{2}{*}{\multicolumn{2}{|c|}{$\begin{array}{l}-0.061 \\
-0.137\end{array}$}} & \multirow{2}{*}{\multicolumn{2}{|c|}{-0.061}} & \multirow{2}{*}{\multicolumn{2}{|c|}{-0.061}} & \multirow{2}{*}{\multicolumn{2}{|c|}{-0.062}} & \multirow{2}{*}{\multicolumn{2}{|c|}{$\begin{array}{l}-0.061 \\
-0.135\end{array}$}} \\
\hline Mean y2008-y2010 & & & & & & & & & & \\
\hline
\end{tabular}




\section{Table 6 The Effect of MLA on the Changes in Investment Level}

The following table presents the results of Prais-Winsten regression of panel-corrected standard error (PCSE) estimates accounting for both heteroskedasticity and serial correlation of the disturbances. The dependent variable (in decimals) is the change in the equity holding of an individual. In our unbalanced panel, including the lagged dependent variable, the total number of observations including zero and non-zero risky financial assets is 2147 from 347 individuals. Corrected $z$-statistics are in parentheses and the significance levels are denoted by asterisks, $* * * 1 \%, * * 5 \%$, and $* 10 \%$ (p-values are two-tailed).

\begin{tabular}{|c|c|c|c|c|c|c|c|c|c|c|}
\hline \multirow[b]{2}{*}{$\Delta$ Equity } & \multicolumn{2}{|c|}{ (1) } & \multicolumn{2}{|c|}{ (2) } & \multicolumn{2}{|c|}{ (3) } & \multicolumn{2}{|c|}{ (4) } & \multicolumn{2}{|c|}{ (5) } \\
\hline & Coef. & $\mathbf{Z}$ & Coef. & $\mathbf{Z}$ & Coef. & $\mathbf{Z}$ & Coef. & $\mathbf{Z}$ & Coef. & $\mathbf{Z}$ \\
\hline Lag $\Delta$ Equity & $-0.434 * * *$ & $(-19.93)$ & $-0.435 * * *$ & $(-20.01)$ & $-0.435 * * *$ & $(-19.97)$ & $-0.434 * * *$ & $(-19.94)$ & $-0.435 * * *$ & $(-20.04)$ \\
\hline Equity & $0.458^{* * *}$ & (21.85) & $0.462 * * *$ & (21.95) & $0.460 * * *$ & (22.03) & $0.461 * * *$ & (21.89) & $0.466^{* * *}$ & $(22.10)$ \\
\hline HELR & $0.030 *$ & $(1.77)$ & $0.030 *$ & $(1.77)$ & 0.028 & $(1.61)$ & $0.033^{*}$ & $(1.91)$ & $0.031 *$ & $(1.78)$ \\
\hline LEHR & 0.032 & $(1.56)$ & 0.032 & $(1.53)$ & 0.032 & (1.54) & $0.034 *$ & $(1.63)$ & 0.033 & (1.59) \\
\hline LELR & $0.068 * * *$ & $(4.32)$ & $0.068^{* * *}$ & $(4.30)$ & $0.065^{* * *}$ & $(4.06)$ & $0.068 * * *$ & $(4.33)$ & $0.065^{* * *}$ & $(4.06)$ \\
\hline Loss Aversion (LA) & 0.000 & $(0.09)$ & 0.000 & $(-0.20)$ & 0.000 & $(0.09)$ & 0.000 & $(0.17)$ & 0.000 & $(-0.12)$ \\
\hline HELR* LA & -0.002 & $(-0.71)$ & -0.001 & $(-0.32)$ & -0.001 & $(-0.67)$ & -0.002 & $(-0.87)$ & -0.001 & $(-0.46)$ \\
\hline LEHR* LA & 0.002 & $(1.03)$ & 0.003 & $(1.18)$ & 0.002 & $(0.88)$ & 0.002 & $(1.06)$ & 0.003 & $(1.05)$ \\
\hline LELR* LA & -0.002 & $(-0.93)$ & -0.001 & $(-0.51)$ & -0.002 & $(-0.92)$ & -0.002 & $(-0.95)$ & -0.001 & $(-0.53)$ \\
\hline Discount Rate & & & $0.140 * *$ & $(2.44)$ & & & & & $0.134 * *$ & $(2.33)$ \\
\hline Time Preferences & & & & & -0.013 & .39) & & & -0.013 & $(-1.33)$ \\
\hline Reference Points: Initial Price & & & & & & & 0.024 & (1.37) & 0.024 & $(1.40)$ \\
\hline Reference Points: Savings account & & & & & & & $0.030 *$ & (1.63) & $0.032 *$ & (1.73) \\
\hline Reference Points: Others & & & & & & & 0.010 & $(0.40)$ & 0.015 & $(0.57)$ \\
\hline Gender (Men) & $-0.027 * *$ & $(-2.44)$ & $-0.025 * *$ & $(-2.27)$ & $-0.028 * * *$ & $(-2.48)$ & $-0.028 * * *$ & $(-2.48)$ & $-0.026 * *$ & $(-2.34)$ \\
\hline Age & $-0.002 * * *$ & $(-3.42)$ & $-0.002 * * *$ & $(-3.54)$ & $-0.002 * * *$ & $(-3.31)$ & $-0.002 * * *$ & $(-3.33)$ & $-0.002 * * *$ & $(-3.34)$ \\
\hline Marriage & $0.032 * * *$ & $(2.93)$ & $0.031 * * *$ & $(2.86)$ & $0.033 * * *$ & $(3.06)$ & $0.030 * * *$ & $(2.76)$ & $0.030 * * *$ & $(2.78)$ \\
\hline Education & 0.000 & $(-0.04)$ & -0.002 & $(-0.18)$ & 0.000 & $(-0.04)$ & 0.000 & $(-0.04)$ & -0.002 & $(-0.21)$ \\
\hline Occupation: Self-employed & $-0.045^{* *}$ & $(-2.18)$ & $-0.043 * *$ & $(-2.08)$ & $-0.047 * *$ & $(-2.24)$ & $-0.047 * *$ & $(-2.28)$ & $-0.047 * *$ & $(-2.24)$ \\
\hline Occupation: Retired & -0.012 & $(-0.77)$ & -0.010 & $(-0.59)$ & -0.013 & $(-0.77)$ & -0.014 & $(-0.86)$ & -0.011 & $(-0.68)$ \\
\hline Occupation: Others & 0.006 & $(0.37)$ & 0.008 & $(0.54)$ & 0.007 & $(0.43)$ & 0.006 & $(0.37)$ & 0.009 & $(0.59)$ \\
\hline$\Delta$ Financial Assets & $0.019 * * *$ & $(2.86)$ & $0.019 * * *$ & $(2.86)$ & $0.019 * * *$ & $(2.83)$ & $0.019 * * *$ & $(2.84)$ & $0.018 * * *$ & $(2.82)$ \\
\hline$\Delta$ Debt ratio & -0.002 & $(-0.75)$ & -0.002 & $(-0,72)$ & -0.002 & $(-0.72)$ & -0.002 & $(-0.75)$ & -0.002 & $(-0.70)$ \\
\hline Year Effect & \multicolumn{2}{|c|}{ Significant } & \multicolumn{2}{|c|}{ Significant } & \multicolumn{2}{|c|}{ Significant } & \multicolumn{2}{|c|}{ Significant } & \multicolumn{2}{|c|}{ Significant } \\
\hline Constant & $-0.057 *$ & $(-1.73)$ & $-0.066 * *$ & $(-2.00)$ & -0.052 & $(-1.57)$ & $-0.083 * *$ & $(-2.24)$ & $-0.087 * *$ & $(-2.35)$ \\
\hline AR(1) Rho & \multirow{2}{*}{\multicolumn{2}{|c|}{$\begin{array}{l}0.321 \\
0.443\end{array}$}} & \multirow{2}{*}{\multicolumn{2}{|c|}{$\begin{array}{l}0.323 \\
0.445\end{array}$}} & \multirow{2}{*}{\multicolumn{2}{|c|}{$\begin{array}{l}0.322 \\
0.444\end{array}$}} & \multirow{2}{*}{\multicolumn{2}{|c|}{$\begin{array}{l}0.321 \\
0.444\end{array}$}} & \multirow{2}{*}{\multicolumn{2}{|c|}{$\begin{array}{l}0.323 \\
0.447\end{array}$}} \\
\hline R-Squared & & 0.443 & & & & & & & & \\
\hline Wald Test & Chi2(1) & Prob. & Chi2(1) & Prob. & Chi2(1) & Prob. & Chi2(1) & Prob. & Chi2(1) & Prob. \\
\hline HELR=LELR & $7.88^{* * * *}$ & 0.005 & $7.89^{* * * *}$ & 0.005 & $7.59 * * *$ & 0.006 & $6.79 * * *$ & 0.009 & $6.32 * * *$ & 0.001 \\
\hline LEHR=LELR & $3.79 * *$ & 0.051 & $3.85^{* *}$ & 0.050 & $3.18^{*}$ & 0.074 & $3.57 *$ & 0.059 & $2.99 *$ & 0.084 \\
\hline Effect of the Crisis & $11.56^{* * * *}$ & 0.001 & $11.34 * * *$ & 0.001 & $11.74 * * *$ & 0.001 & $11.66^{* * *}$ & 0.001 & $11.61 * * *$ & 0.001 \\
\hline Mean y2000-y2007 & \multicolumn{2}{|c|}{-0.010} & \multicolumn{2}{|c|}{-0.010} & \multicolumn{2}{|c|}{-0.009} & \multicolumn{2}{|c|}{-0.009} & \multicolumn{2}{|c|}{-0.009} \\
\hline Mean y2008-y2010 & \multicolumn{2}{|c|}{0.023} & & & & & & & & \\
\hline
\end{tabular}




\section{Table 7 The Effect of MLA on the Discretionary Changes in Investments}

The following table presents the results of Prais-Winsten regression of panel-corrected standard error (PCSE) estimates accounting for both heteroskedasticity and serial correlation of the disturbances. The dependent variable is the change in the equity holding of an individual, corrected for the market return over the period. In our unbalanced panel, including the lagged dependent variable, the total number of observations including zero and non-zero risky financial assets is 2147 from 347 individuals. Corrected $z$-statistics are in parentheses and the significance levels are denoted by asterisks, *** 1\%, ** 5\%, and * 10\% (p-values are two-tailed).

\begin{tabular}{|c|c|c|c|c|c|c|c|c|c|c|}
\hline \multirow[b]{2}{*}{ D. Equity } & \multicolumn{2}{|c|}{ (1) } & \multicolumn{2}{|c|}{ (2) } & \multicolumn{2}{|c|}{ (3) } & \multicolumn{2}{|c|}{ (4) } & \multicolumn{2}{|c|}{ (5) } \\
\hline & Coef. & $\mathbf{z}$ & Coef. & $\mathbf{z}$ & Coef. & $\mathbf{z}$ & Coef. & $\mathbf{z}$ & Coef. & $\mathbf{z}$ \\
\hline Lag D. Equity & $-0.430^{* * *}$ & $(-19.24)$ & -0.430 **** & $(-19.29)$ & $-0.429 * * *$ & $(-19.23)$ & -0.430 *** & $(-19.32)$ & $-0.430 * * *$ & $(-19.38)$ \\
\hline Equity & $0.421 * * *$ & $(20.76)$ & $0.424 * * *$ & $(20.82)$ & $0.422 * * *$ & $(20.88)$ & $0.426 * * *$ & (20.87) & $0.429 * * *$ & $(21.03)$ \\
\hline HELR & 0.026 & $(1.58)$ & 0.026 & $(1.57)$ & 0.024 & $(1.45)$ & $0.029 *$ & $(1.75)$ & $0.027 *$ & $(1.63)$ \\
\hline LEHR & $0.034 *$ & $(1.76)$ & $0.034 *$ & (1.74) & $0.034 *$ & $(1.75)$ & $0.036^{*}$ & (1.84) & $0.035^{*}$ & (1.80) \\
\hline LELR & $0.062 * * *$ & (4.08) & $0.061 * * *$ & $(4.07)$ & $0.059 * * *$ & $(3.85)$ & $0.062 * * *$ & (4.11) & $0.059 * * *$ & (3.86) \\
\hline Loss Aversion (LA) & 0.000 & $(0.06)$ & 0.000 & $(-0.18)$ & 0.000 & $(0.06)$ & 0.000 & $(0.13)$ & 0.000 & $(-0.10)$ \\
\hline HELR* LA & -0.002 & $(-0.70)$ & -0.001 & $(-0.36)$ & -0.002 & $(-0.67)$ & -0.002 & $(-0.87)$ & -0.001 & $(-0.52)$ \\
\hline LEHR* LA & 0.001 & $(0.32)$ & 0.001 & $(0.46)$ & 0.000 & $(0.21)$ & 0.001 & $(0.36)$ & 0.001 & $(0.39)$ \\
\hline LELR* LA & -0.002 & $(-0.86)$ & -0.001 & $(-0.51)$ & -0.002 & $(-0.85)$ & -0.002 & $(-0.88)$ & -0.001 & $(-0.52)$ \\
\hline Discount Rate & & & $0.120 * *$ & $(2.16)$ & & & & & $0.115^{* *}$ & $(2.06)$ \\
\hline Time Preferences & & & & & -0.011 & $(-1.21)$ & & & -0.011 & $(-1.17)$ \\
\hline Reference Points: Initial Price & & & & & & & 0.025 & $(1.47)$ & 0.025 & $(1.49)$ \\
\hline Reference Points: Savings account & & & & & & & $0.032 *$ & $(1.81)$ & $0.034 *$ & $(1.90)$ \\
\hline Reference Points: Others & & & & & & & 0.013 & $(0.52)$ & 0.016 & $(0.68)$ \\
\hline Gender (Men) & $-0.025^{* *}$ & $(-2.41)$ & $-0.024 * *$ & $(-2.26)$ & $-0.026 * * *$ & $(-2.45)$ & $-0.026^{* * *}$ & $(-2.46)$ & $-0.025^{* *}$ & $(-2.33)$ \\
\hline Age & $-0.002 * * *$ & $(-3.26)$ & $-0.002 * * *$ & $(-3.37)$ & $-0.001 * * *$ & $(-3.16)$ & $-0.001 * * *$ & $(-3.17)$ & $-0.002 * * *$ & $(-3.18)$ \\
\hline Marriage & $0.029 * * *$ & $(2.81)$ & $0.028^{* * *}$ & $(2.74)$ & $0.030 * * *$ & $(2.91)$ & $0.027 * * *$ & $(2.61)$ & $0.027^{* * *}$ & $(2.63)$ \\
\hline Education & -0.002 & $(-0.21)$ & -0.003 & $(-0.34)$ & -0.002 & $(-0.21)$ & -0.002 & $(-0.24)$ & -0.004 & $(-0.39)$ \\
\hline Occupation: Self-employed & $-0.040 * *$ & $(-2.05)$ & $-0.039 * *$ & $(-1.96)$ & $-0.041 * *$ & $(-2.09)$ & $-0.043 * *$ & $(-2.16)$ & $-0.042 * *$ & $(-2.12)$ \\
\hline Occupation: Retired & -0.013 & $(-0.82)$ & -0.010 & $(-0.65)$ & -0.013 & $(-0.82)$ & -0.014 & $(-0.92)$ & -0.012 & $(-0.75)$ \\
\hline Occupation: Others & 0.007 & $(0.46)$ & 0.009 & $(0.61)$ & 0.007 & $(0.50)$ & 0.007 & $(0.45)$ & 0.010 & $(0.65)$ \\
\hline$\Delta$ Financial Assets & $0.021 * * *$ & $(3.10)$ & $0.021 * * *$ & (3.11) & $0.020 * * *$ & $(3.08)$ & $0.020 * * *$ & $(3.08)$ & $0.020 * * *$ & $(3.07)$ \\
\hline$\Delta$ Debt ratio & 0.000 & $(-0.15)$ & 0.000 & $(-0.14)$ & 0.000 & $(-0.13)$ & 0.000 & $(-0.15)$ & 0.000 & $(-0.13)$ \\
\hline Year Effect & \multicolumn{2}{|c|}{ Significant } & \multicolumn{2}{|c|}{ Significant } & \multicolumn{2}{|c|}{ Significant } & \multicolumn{2}{|c|}{ Significant } & \multicolumn{2}{|c|}{ Significant } \\
\hline Constant & $-0.090 * * *$ & $(-2.83)$ & $-0.098 * * *$ & $(-3.06)$ & $-0.085^{* * *}$ & $(-2.69)$ & $-0.117 * * *$ & $(-3.28)$ & $-0.121 * * *$ & $(-3.35)$ \\
\hline AR(1) Rho & \multirow{2}{*}{\multicolumn{2}{|c|}{$\begin{array}{l}0.284 \\
0.148\end{array}$}} & \multirow{2}{*}{\multicolumn{2}{|c|}{$\begin{array}{l}0.284 \\
0.419\end{array}$}} & \multirow{2}{*}{\multicolumn{2}{|c|}{$\begin{array}{l}0.283 \\
0.418\end{array}$}} & \multirow{2}{*}{\multicolumn{2}{|c|}{$\begin{array}{l}0.286 \\
0.420\end{array}$}} & \multirow{2}{*}{\multicolumn{2}{|c|}{$\begin{array}{l}0.280 \\
0.421\end{array}$}} \\
\hline R-Squared & & & & & & & & & & \\
\hline Wald Test & Chi2(1) & Prob. & Chi2(1) & Prob. & Chi2(1) & Prob. & Chi2(1) & Prob. & Chi2(1) & Prob. \\
\hline HELR=LELR & $7.75^{* * * *}$ & 0.005 & $7.75^{* * * *}$ & 0.005 & $7.45 * * *$ & 0.006 & $6.49 * * *$ & 0.011 & $6.06 * *$ & 0.014 \\
\hline LEHR=LELR & 2.47 & 0.116 & 2.50 & 0.114 & 2.01 & 0.157 & 2.28 & 0.131 & 1.81 & 0.179 \\
\hline Effect of the Crisis & $21.22 * * *$ & 0.000 & $20.97 * * *$ & 0.000 & $21.42 * * *$ & 0.000 & $21.41 * * *$ & 0.000 & $21.35 * * *$ & 0.000 \\
\hline Mean y2000-y2007 & \multicolumn{2}{|c|}{0.026} & \multicolumn{2}{|c|}{0.025} & \multicolumn{2}{|c|}{0.026} & \multicolumn{2}{|c|}{0.027} & \multicolumn{2}{|c|}{0.027} \\
\hline Mean y2008-y2010 & \multicolumn{2}{|c|}{0.069} & \multicolumn{2}{|c|}{0.069} & \multicolumn{2}{|c|}{0.070} & \multicolumn{2}{|c|}{0.071} & \multicolumn{2}{|c|}{0.070} \\
\hline
\end{tabular}




\section{Appendix A: Variable Definitions}

\section{Dependent variables:}

Equity: The proportion of the financial assets invested in equities.

$\Delta$ Equity: The year-on-year change in Equity, measured in decimal.

D.Equity: The net year-on-year change in Equity, corrected for the impact of the market return.

\section{Explanatory variables:}

Level of Myopia $=$

HEHR: high evaluation and high rebalancing frequencies; omitted as a reference category

HELR: high evaluation and low rebalancing frequencies $=1$, if yes; 0 , if no.

LEHR: low evaluation and high rebalancing frequencies $=1$, if yes; 0 , if no.

LELR: low evaluation and low rebalancing frequencies $=1$, if yes; 0 , if no.

Loss Aversion $(L A)=$ coefficient of loss aversion estimated using the procedure described in Dimmock and Kouwenberg (2010).

Discount Rate $=$ coefficient of discount rate estimated using the procedure described in Dimmock and Kouwenberg (2010).

Level of Time preference $=1$, for long-term; 0 if short-term.

Reference Points $=$ Looking at initial investment price $=1$, if yes; 0 , if no.

Looking at return on savings account $=1$, if yes; 0 , if no.

Looking at market return (Omitted as a reference category)

Looking at other reference points $=1$, if yes; 0 , if no.

Gender $=1$, if male; 0 if female.

Age $=$ Actual age

Marriage Status $=1$, if married; 0 if single.

Education $=1$, if university or college graduate; 0 if below .

Occupation = Regular employment; omitted as a reference category

Self-employed $=1$, if yes; 0 , if no.

Retired $=1$, if yes; 0 , if no.

Others $=1$, if yes; 0 , if no.

Financial Assets $=$ Total Financial Assets in $€ / 100,000$

Debt Ratio $=$ Total Debts/Total Assets 